\title{
REDIMAT
}

Journal of Research in Mathematics Education

Instructions for authors, subscriptions and further details:

http://redimat.hipatiapress.com

\section{CAS Assisted Proofs in Upper Secondary School Mathematics Textbooks}

Uffe Thomas Jankvist 1

Morten Misfeldt2

1) Aarhus University, Denmark

2) University of Copenhagen, Denmark

Date of publication: October 24th, 2019

Edition period: October 2019-February 2020

To cite this article: Jankvist, U.T. \& Misfeldt, M. (2019). CAS assisted proofs in upper secondary school mathematics textbooks. REDIMATJournal of Research in Mathematics Education, 8(3), 232-266. doi:

10.17583/redimat.2019.3315

To link this article: http://dx.doi.org/10.17583/redimat.2019.3315

\section{PLEASE SCROLL DOWN FOR ARTICLE}

The terms and conditions of use are related to the Open Journal System and to Creative Commons Attribution License (CCAL). 


\section{CAS Assisted Proofs in Upper Secondary School Mathematics Textbooks}

Uffe Thomas Jankvist Aarhus University
Morten Misfeldt

University of Copenhagen

(Received: 20 February 2018; Accepted: 05 October 2019; Published: 24 October 2019)

\section{Abstract}

This article addresses the didactical effects of CAS assisted proofs in Danish upper secondary mathematics textbooks as a result of the 2005 reform that introduced CAS as a part of the upper secondary level curriculum (and examinations). Based on a reading of 33 upper secondary school mathematics textbooks, 38 instances of CAS assisted proofs are identified in ten different textbooks. The CAS based proofs in these textbooks are of three types: complete outsourcing of the proof to CAS; partial outsourcing of the proof to CAS; and additional verification of the proof' correctness by CAS. The analyses draw on theoretical constructs related to both proofs and proving (e.g. proof schemes) and to use of digital technologies in mathematics education (lever potential, blackboxing, instrumental genesis). In particular, the analyses make use of a distinction between epistemic, pragmatic and justificational mediations. Results suggest both potential problems with using CAS as an integrated part of deductive mathematical proofs in textbooks, since it appears to promote undesired proof schemes with the students, and difficulties with understanding these problems using the constructs of epistemic and pragmatic mediations that are often adopted in the literature regarding CAS use in mathematics teaching and learning.

Keywords: Mathematical proof, CAS assisted proofs, proof schemes, instrumental genesis, justificational mediations 


\section{Demostraciones Asistidas por CAS en Libros de Texto de Matemáticas de Secundaria Superior}

Uffe Thomas Jankvist Aarhus University
Morten Misfeldt

University of Copenhagen

(Recibido: 20 Febrero 2018; Aceptado: 05 Octubre 2019; Publicado: 24 Octubre 2019)

\section{Resumen}

Este artículo aborda los efectos didácticos de las demostraciones asistidas por CAS en los libros de texto daneses de matemáticas de secundaria superior. A partir de la lectura de 33 libros de texto de matemáticas de secundaria superior, se identifican 38 casos de pruebas asistidas por CAS en diez libros diferentes. Las pruebas basadas en CAS en estos libros son de tres tipos: externalización completa de la prueba a CAS; externalización parcial de la prueba a CAS; y verificación adicional de la corrección de la prueba en CAS. Los análisis se basan en construcciones teóricas relacionas tanto con las demostraciones como con las pruebas (por ejemplo, esquemas de demostración) y con el uso de tecnologías digitales en la educación matemática. Los análisis hacen uso de una distinción entre mediaciones epistémicas, pragmáticas y justificativas. Los resultados sugieren problemas potenciales con el uso de CAS como parte integrada de pruebas matemáticas deductivas en los libros de texto, ya que parecen promover esquemas de demostración no deseados en los estudiantes, así como dificultades para comprender estos problemas usando las construcciones de mediaciones epistémicas y pragmáticas que a menudo se adoptan en la literatura sobre el uso de CAS en la enseñanza y aprendizaje de las matemáticas.

Palabras clave: Demostraciones matemáticas, demostraciones asistidas por CAS, esquemas de demostración, génesis instrumental, mediaciones justificativas 


\section{Jankvist \& Misfeldt-CAS Assisted Proofs}

s part of a reform of the Danish upper secondary school in 2005, CAS entered in at all levels of the upper secondary mathematics program. It entered into the final written national examinations, into the classroom teaching and into the textbooks. Except for a few guiding remarks in the ministerial regulations (UVM, 2013) that the role of CAS was not only to be a tool for solving problems, etc. but also an instrument for underpinning conceptual understanding, the actual implementation of CAS into the mathematics program was pretty much left up to the schools, the teachers, and not least the textbook authors. This left the textbook authors of more than one textbook system to invent the notion of "CAS proofs" 1 - or "CAS assisted proofs" as termed by Dana-Picard (2005). Of course, the notion of computer-assisted proofs has been around for a while in the discipline of mathematics, e.g. the proof for the four-color problem (Appel \& Haken, 1977). But a Computer Algebra System (CAS) assisted proof is something quite different. As an example, take the following one from a third and final year upper secondary mathematics textbook. The theorem ("sætning") to be proved is that "The functions cosine and sine are differentiable in every real number $x$, and $\cos ^{\prime}(x)=-\sin (x), \sin ^{\prime}(x)=\cos (x)$." (Clausen, Schomacker \& Toln $\varnothing, 2007$, p. 12). As for the "proof" the authors write: "We provide a CAS proof, cf. figure 109", i.e. a screenshot from what appears to be a TI-89.

\section{Vi giver et CAS-bevis, jf. figur 109.}
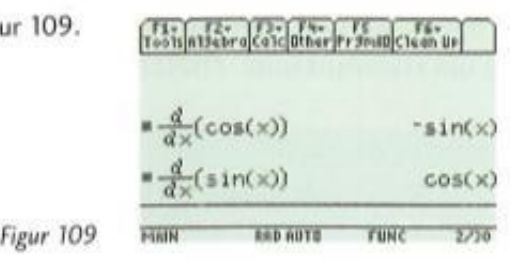

Bevis

Figur 109

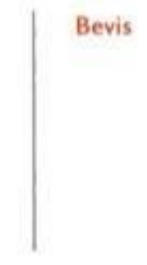

Figure 1. "We provide a CAS-proof..." (Clausen, Schomacker \& Toln $\varnothing, 2007$, p. 13).2

Dana-Picard (2005) argues that CAS can indeed be a legitimate part of the process of proving an abstract theorem, and Elbaz-Vincent (2005) exemplifies how CAS may be a valuable assistant in students' reasoning processes, not least in relation to symbolic integration. Still, neither seems to be the case in the example above, where no means for reasoning and 
explanation whatsoever are provided for the students, and where the entire act of "proving" is outsourced to the CAS tool. Rather what seems to be going on is that the CAS carries out all reasoning for the students, which does not support the development of mathematical reasoning abilities.

Eventually "proofs" like that above led us to dig deeper into the Danish upper secondary school textbooks' use of CAS in relation to proofs and proving activities. Besides examples of "proofs" as that above, we found examples of intermediate steps of a proof, e.g. involving algebraic manipulations, reductions, etc. being outsourced to CAS. In some instances, this might appear to serve a didactical purpose, but we also found instances where steps rather crucial for the understanding of the proof were outsourced to CAS. Furthermore, we saw several instances where a use of CAS was sort of "added on" to a traditional proof in order to play the role of an "authority" upon which the correctness of traditional proofs was valued or judged. The current article offers an in-depth analysis of such CAS assisted proofs in mathematics textbooks for Danish upper secondary school. As part of this study we draw on selected constructs from research on proof and proving in mathematics education (e.g. the notion of proof schemes) and from research on digital technologies in the teaching and learning of mathematics (e.g. lever potential and blackboxing). In particular we also draw on the framework of instrumental genesis and the notion of epistemic and pragmatic value of CAS use. Following the terminology from Rabardel we distinguish epistemic and pragmatic mediations to describe different use of technology (Rabardel \& Bourmaud, 2003). Due to the nature of the investigation at hand and the empirical data from textbooks, we have come to augment this framework with a third kind of mediations; justificational mediations (Misfeldt \& Jankvist, 2018; Jankvist, Misfeldt \& Aguilar, in press). But before getting to that we first account for our quantitative analysis of Danish upper secondary school mathematics textbooks.

\section{CAS in Danish Upper Secondary School Mathematics Textbooks}

In order to find out how and to what extent CAS is used in Danish mathematics textbooks for upper secondary school, we have read through 33 of the most popular textbooks for upper secondary school looking for how CAS is used. Danish upper secondary school encompasses three different streams: the classical stream (stx); the technical stream (htx); and the 
business stream (hhx). Our selection includes textbooks from all three streams.

CAS is an integral part of Danish upper secondary mathematics education. Hence, it is expected that all textbooks relate to CAS to some extent. What we found, however, is a great diversity in how much and for what purposes CAS is being used. Looking at the Danish textbooks, we see books that barely use CAS and books with almost a hundred instances of CAS use. In total we found 754 instances of CAS use in the 33 books. Initially we discriminated these instances into CAS use: in proofs; in relation to conceptual exploration and explanation; in introductory sections (e.g. introducing a new chapter); in macros where CAS techniques are described; and in examples (see table 1 and appendix A for a full description of and reference to the analyzed sources).

Table 1.

Number of uses of CAS in 33 Danish upper secondary school mathematics textbooks.

\begin{tabular}{cccccc}
\hline $\begin{array}{c}\text { CAS in } \\
\text { proofs }\end{array}$ & $\begin{array}{c}\text { CAS in } \\
\text { conceptual } \\
\text { work }\end{array}$ & $\begin{array}{c}\text { CAS in } \\
\text { introductory } \\
\text { text }\end{array}$ & $\begin{array}{c}\text { CAS in } \\
\text { macros }\end{array}$ & $\begin{array}{c}\text { CAS in } \\
\text { examples }\end{array}$ & $\begin{array}{c}\text { Other uses of } \\
\text { CAS }\end{array}$ \\
\hline 38 & 44 & 24 & 47 & 586 & 3 \\
\hline
\end{tabular}

It is not surprising that the most typical use of CAS in the mathematics textbooks is in the examples. However, as seen from table 1, CAS is also used in proofs. In fact, almost a third of the analyzed textbooks make use of CAS in proofs. As already hinted to, the CAS uses in proofs are of different types. In order to account for this, we first introduce the theoretical constructs underlying our pending analyses of these CAS assisted proofs.

\section{Theoretical Constructs Related to Proofs and Proving}

As aptly phrased by Duval (2007, p. 137), "Proof constitutes a crucial threshold in the learning of mathematics. Why do so many students not succeed in truly crossing it?" One reason is given by the Education Committee of EMS in their series of "Solid Findings" articles: 
Mathematical thought concerning proof is different from thought in all other domains of knowledge, including the sciences as well as everyday experience; the concept of formal proof is completely outside mainstream thinking. Teachers of mathematics at all levels [...] thus require students to acquire a new, non-natural basis of beliefs when they ask them to prove... (Education Committee of EMS, 2011, p. 51)

Dreyfus makes the observation that:

Indeed, research results on students' conceptions of proof are amazingly uniform; they show that most high school and college students don't know what a proof is nor what it is supposed to achieve. Even by the time they graduate from high school, most students have not been enculturated into the practice of proving, or even justifying the mathematical processes they use. (Dreyfus, 1999, p. 94)

Besides the differences to everyday reasoning, students' difficulties with proof also stem from that they might never have been told what actually counts as a mathematical argument. According to Dreyfus, one reason is that in many textbooks "more or less formal arguments are used, together with visual or intuitive justifications, generic examples, and naive induction" but that "students are rarely if ever given any indications whether mathematics distinguishes between these forms of argumentation or whether they are all acceptable" (p. 97). Students, says Dreyfus, have only few if any means to distinguish between such different forms of argumentation. This is backed by Duval (2007, p. 159), who distinguishes two kinds of failures on students' behalf: (1) "Dysfunctions in valid reasoning, such as status confusion, nondistinction between a statement and its converse, etc." (2) "Gaps of deficiencies in the progress of a proof". (For Duval, "status confusion" also refers to the different status of statements within a proof, e.g. hypothesis, property, and conclusion.)

Taking a step back we might ask what the role and function of mathematical proof is in mathematics and in mathematics education. Clearly, the first thing that comes to mind is the verification of truth of a given statement (or theorem). De Villiers (1990) points out that although this is surely one purpose and function of mathematical proof, it is far from the only one - and not necessarily the most beneficial one from an educational perspective either. In fact, he points out five different functions of mathematical proof: (1) the above mentioned conviction and verification; (2) 


\section{Jankvist \& Misfeldt-CAS Assisted Proofs}

as a means for explaining why a given mathematical result is true; (3) to systematize different mathematical results in deductive systems of axioms, concepts, theorems, etc.; (4) as a way of discovering new results and new knowledge in the already existing mathematical systems/theories; (5) and finally as a way of communicating mathematical knowledge. In particular the distinction between proofs that prove, and proofs that explain (and prove) is didactically crucial (Hanna, 1989). While the first kind only shows that a theorem is true, i.e. is concerned with substantiation, the second kind shows why a theorem is true, i.e. "it provides a set of reasons that derive from the phenomenon itself" (Hanna, 1990, p. 9). Or in the words of Steiner (1978, p. 143), "an explanatory proof makes reference to a characterizing property of an entity or structure mentioned in the theorem, such that from the proof it is evident that the results depend on that property." Technology used in proving activities obviously plays a potential part in increasing the distance between understanding and justification as e.g. argued by Tymoczko (1979) with reference to the classical proof of the four-color theorem. Proofs by brute (computer) force challenges the human involvement in the proving process, and hence also the human understanding.

Harel and Sowder (2007, p. 809) state that: "A person's (or a community's) proof scheme consists of what constitutes ascertaining and persuading for that person (or community)." Ascertaining is the process employed to remove one's own doubts about the truth of an assertion, while persuading is the process employed to remove other's doubts. According to Harel and Sowder, ascertaining and persuading are both subprocesses of the process of proving. Ascertaining and persuading are both entirely subjective, since one's proving may vary from context to context, and proving may vary from person to person, or within a community over time. Hence, the above definition of a proof scheme. This also means that an individual may be convinced by other things concerning proof than the usual deductive reasoning patterns accepted within the field of mathematics. Harel and Sowder (2007) provide a taxonomy consisting of three overall classes of proof schemes: (1) external conviction proof schemes; (2) empirical proof schemes; (3) deductive proof schemes. The external conviction proof schemes may be expressed by an authoritarian proof scheme, e.g. that something is true because the teacher or the textbook says so; a ritual proof scheme, e.g. that a geometry proof must have a two-column format; or a nonreferential symbolic proof scheme, e.g. that a proof must contain symbols 
and symbol manipulations. The empirical proof schemes come into play when using examples to justify the truth of general (universal) statements. As the reader might very well know, some students may be convinced of the correctness of a given mathematical relationship by means of two or three specific empirical examples or by what may be perceived as a "crucial" empirical example. Finally, the deductive proof schemes are those which we know from the discipline of mathematics, covering direct proof, including axiomatic proofs, proof by contradiction, induction proofs, combinatorial proofs, etc. (Harel and Sowder also subcategorize the empirical and the deductive proof schemes, but for the purpose of our pending analyses the above shall suffice.) In relation to technology use in proving there is an ongoing discussion if proofs which are strictly dependent on technology (such as the four-color theorem computer proof) maintain their a priori status (as claimed by McEvoy, 2008), or if they are similar to other external conviction arguments (as argued by Tymoczko, 1979). The discussion of apriority and fallibility of computer based techniques continues in relation to the emerging discipline of experimental mathematics (see Johansen and Misfeldt, 2016), where the dependence of, and benefits from, computer calculations, make it important to reflect upon the details of the interplay between mathematical thinking, computer calculations and secure mathematical knowledge (Borwein, 2005).

In the analyses to come we build on the distinction from Hanna (1990) between proofs that explain and proof that (only) prove, and on the concept of proof schemes from Harel and Sowder (2007). Hence, we talk about explanatory and justificatory functions of proofs as well as external conviction proof schemes, empirical proof schemes, and deductive proof schemes. And we do so together with selected central constructs related to the use of digital technology, in particular of course CAS, in mathematics teaching. We explain these next.

\section{Theoretical Constructs Related to the Use of CAS in Teaching}

There is an extensive literature about the use of CAS in mathematics education. However, not much of this literature relate to the development of students' ability to proof. This does not mean that the knowledge about the influence from CAS on mathematical thinking, learning and teaching is without relevance to the present investigation. Recent reviews of CAS use in 


\section{Jankvist \& Misfeldt-CAS Assisted Proofs}

education (Hoyles, 2014; Hoyles \& Lagrange 2010; Laborde \& Strässer, 2010; Lavicza, 2010) point to the transformation of teaching and learning processes in mathematics that these technologies provide. In a sense CAS increases both the potentials and the problems that already exist in the teaching and learning of mathematics (Niss, 1999). Concerning technology in the teaching and learning of mathematics, Artigue states that

what counts is the potential that CAS offers for obtaining results very quickly, for reconsidering a previous computation and substituting a parameter to a numerical value in it, and the help CAS can offer as assistants to computation and symbolic proofs for students with limited technical background. (Artigue, 2002, p 268)

Such "assistants" in relation to CAS in computation and symbolic proofs may be described, in particular, with the concepts of lever potential and blackboxing, which both address the way in which technology is able to assist teachers and students by handling technical operations that are redundant to mathematics learning. More precisely, the lever potential in a technology environment is the positive effects that CAS offers in terms of focusing the students' attention on the most relevant activity (Dreyfus, 1994; Winsløw, 2003). A use of technology as a lever potential can help save time, increase the mathematical capacity of each student, and focus activities in the classroom (Dreyfus, 1994). The lever potential works by outsourcing certain mathematical processes, and thus directing attention away from these processes. But such outsourcing is hard to control and can easily lead to problems with understanding what is actually going on, since it also involves blackboxing. This negative effect of outsourcing, i.e. blackboxing, is well described in the literature on CAS and mathematics learning (e.g. Buchberger, 2002; Lagrange, 2005), and so are the results of students who are able to perform CAS-based mathematical activities, but unable to understand the underlying processes (e.g. Jankvist \& Misfeldt, 2015; Jankvist, Misfeldt \& Marcussen, 2016; Jankvist, Misfeldt \& Aguilar, 2019). Thus, blackboxing leaves students dependent on certain tools and with little experience of performing the low-level mathematical processes that are necessary without the tool (Nabb, 2010).

The instrumental approach to the use of CAS in mathematics teaching and learning studies the development of instrumented techniques, where the artefact "CAS" is developed into a personal instrument by the student (Artigue, 2002; Trouche, 2005). This process is considered bidirectional in 
the sense that the student modifies and adapts the tool for his or her own purposes, while simultaneously being subordinated to the affordances of the tool. The instrumented techniques have both pragmatic and epistemic value, and the distinction between the two has shown to be insightful in the educational analysis of CAS use (Artigue, 2002; Lagrange, 2005). The pragmatic value focuses on the productive potential, whereas the epistemic value focuses on learning and understanding (Artigue, 2002). The distinction between epistemic and pragmatic values of instrumented techniques builds on Verillon and Rabardel (1995), as described by Artigue (2002) and Trouche (2005). Verillon and Rabardel (1995) draw on the Vygotskian concept of mediation, in the sense that they consider instruments as artifacts that mediate between user and the objective of the activity. Using this idea, the distinction between epistemic and pragmatic mediations is described and exemplified with a magnifier and a hammer in the later contribution by Rabardel and Bourmaud (2003). (See Misfeldt and Zacho (2016) for a thorough description of the instrumental approach with an outset in the concept of mediation.)

Using the concept of mediation, we can state an important insight from the instrumental approach; namely that epistemic mediations are critical for CAS to have educational value (Artigue, 2010). However, considering proving activities, and in particular students' reading of proofs in textbooks, the distinction between epistemic and pragmatic mediations becomes weaker and more blurred. Rather it makes sense to distinguish between three critical mediations of CAS (Misfeldt \& Jankvist, 2018):

1. CAS use for justification (justificational mediations),

2. CAS use for conveying meaning and understanding (epistemic mediations), and

3. CAS use for solving tasks or satisfy other external needs (pragmatic mediations).

Mediations toward establishing truth are neither clearly epistemic, nor only pragmatic, rather they build on the distinction from Hanna (1990) between proofs that explain and proofs that (only) prove. Hence, we suggest talking about not only epistemic and pragmatic mediations, but also justificational mediations when addressing the use of CAS in proof in textbooks through the instrumental approach. In our pending analyses, we shall rely on these three kinds of mediations along with the notion of proof schemes to describe the CAS assisted proofs. 


\section{Research Method}

As seen in the previously presented table 1, we found use of CAS in 38 mathematical proofs in textbooks, distributed in ten textbooks. Of these ten textbooks, one was for 1st year upper secondary school level, four were for 2nd year level, and five were for 3rd year level. These books are published by three different publishing houses (cf. Appendix A). Looking closely at the 38 instances of CAS assisted proofs, we have identified three different types of such.

Type 1 is the complete outsourcing to CAS. We saw an example in figure 1. In such cases, CAS mainly serve the role of a justificational mediation, although pragmatic mediations may play a minor role.

Type 2 is the partial outsourcing to CAS. In a partial outsourcing, one or several "steps" of the proof is carried out by CAS. Depending on the nature of the partial outsourcing - and the purpose of the textbook authors - this may serve either one of the three types of mediations. In cases where CAS serves as a lever potential, e.g. by directing attention to the overall structure of the proof rather than minor details (Ottesen, 2009), epistemic mediations may be in play. Pragmatic mediations may also be in play, e.g. by relying on CAS to perform trivial computations or checking a given number of possible cases, etc. Justificational mediations may occur, say, if a step of a proof relies on elements which the students have not yet been taught, or is outside curriculum. Any combination of the three types of mediations may of course be in play.

Type 3 is additional verification by CAS. Often for this type of use, a traditional mathematical proof is provided first and then followed by a sort of "check" with CAS. This is not unlike the use of CAS to check results as part of examples, and in fact it may be a kind of "spillover" from such use of CAS in the textbooks. Nevertheless, the phenomenon is so widespread that we have decided to regard it as its own specific type of use in relation to CAS use in proofs in textbooks. Such a use of CAS first and foremost plays the role of a justificational mediation. 
Table 2.

The number of instances of CAS assisted proofs in Danish mathematics textbooks for upper secondary school according to their type and level.

\begin{tabular}{llll}
\hline $\begin{array}{l}\text { School } \\
\text { year }\end{array}$ & $\begin{array}{l}\text { Type 1 complete } \\
\text { outsourcing }\end{array}$ & $\begin{array}{l}\text { Type 2 partial } \\
\text { outsourcing }\end{array}$ & $\begin{array}{l}\text { Type 3 additional } \\
\text { verification }\end{array}$ \\
\hline Year 1 & 0 & 1 & 1 \\
Year 2 & 5 & 9 & 7 \\
Year 3 & 3 & 3 & 9 \\
Total & 8 & 13 & 17 \\
\hline
\end{tabular}

Depending on the type of CAS assisted proof and kind of mediations in play, this may affect students' proof schemes - either already possessed proof schemes or those in development - in an inexpedient fashion. As we shall illustrate with the following analyses, CAS may potentially come to play and be viewed as - an external authority. Hence, from a research methodological point of view, the three kinds of mediations (epistemic, pragmatic and justificational), building also on the distinction between proofs that explain and proves that prove, along with the notion of proof schemes make up the theoretical basis for our further empirical analyses of the three types of CAS assisted proofs.

\section{Type 1: Complete outsourcing to CAS}

The eight examples of proofs with complete outsourcing to CAS cover proofs for the vertex formula for the quadratic function, derivatives of standard functions, e.g. exponential functions, power functions, and trigonometric functions as illustrated in figure 1.

One of the first questions that come to mind when seeing the so-called "CAS proof" presented in the introduction (figure 1) is if this is some kind of a joke? From a mathematical point of view, it could be interpreted as such. Of course, this is not a "proof" - it is a circular reference; the theorem is true, because the CAS tool is programmed to say that it is true. However, from a 
didactical point of view, it may be less funny. Because even though the teachers may get the mathematical joke, it is dead certain that there are several students who will not. Hence, from a didactical point of view, if this "proof" is a joke played on the Danish 2005 reform and its inclusion of CAS, it may end up being at the students' expense.

A use of CAS in the manner that it is used to "prove" the differential quotients of sine and cosine is one that more or less compromises all of the potential functions of mathematical proof (cf. De Villiers, 1990), in particular that of explanation (Hanna, 1990). However, CAS does mediate the verification of the result. The mediation is not epistemic, since the use of the CAS does not explain why $\sin ^{\prime}(x)=\cos (x)$, nor why $\cos ^{\prime}(x)=-\sin (x)$. In relation to proof schemes this CAS assisted proof simply undermines any potential development of a deductive proof scheme on the students' behalf. And worse so, it actually seems to support an external conviction scheme, namely that of the authoritarian proof scheme. Only, now it is neither true because the teacher nor the textbook says so, but because CAS says so! As for the perspectives provided to us from the technology literature, an outsourcing of the verification to CAS certainly does not serve as a lever potential in this case; everything is completely blackboxed. It does, however, ensure that the result will be true. In this way such justificational mediations resemble some of the problems in purely pragmatic use of CAS as described in the literature. This is similar to Artigue's (2010) description of CAS use for problem solving that only focuses on pragmatic mediations leads to educational problems; the same is true for proof practice building on CAS only focusing on justificational mediations.

\section{Type 2: Partial outsourcing to CAS}

Of the 13 instances of proofs in textbooks involving partial outsourcing to CAS, the majority has to do with simplifying or carrying out algebraic manipulations, including e.g. polynomial division. Also, CAS is used to find limits (cf. the example below). All of the identified uses are rather pragmatic of nature. Only on two instances is CAS used to convey more justificational mediations. Once it is used to test if a given function fulfills a differential equation, and once it is used to evaluate if two expressions are equal to each other. In general, the majority of the partial outsourcings do not potentially contribute to enhancing students' understanding of what may be going on in 
the proof. We exemplify this through one of the instances relying on CAS to find a limit.

\section{DEN NATURLIGE LOGARITMEFUNKTION}

Vi vil finde den afledede af den naturlige logaritmefunktion $\ln x$, og går igen frem efter 3-trinsreglen.

1. trin. Først funktionstilvæksten:

$$
\Delta y=\ln (x+h)-\ln x=\ln \frac{x+h}{x}=\ln \left(1+\frac{h}{x}\right) .
$$

Her har vi brugt regnereglen for logaritmer:

$$
\ln a \cdot \ln b=\ln \frac{a}{b} .
$$

2. trin. Dernæst skriver vi differenskvotienten op:

$$
\frac{\Delta y}{h}=\frac{\ln \left(1+\frac{h}{x}\right)}{h} \text {. }
$$

3. trin. Til sidst skal vi om muligt finde grænseværdien for denne brøk, når $h$ går mod 0 . Dette kræver en del overvejelser, som vi forbigår her. Vi benytter cas og finder, at

$$
\frac{\ln \left(1+\frac{h}{x}\right)}{h} \rightarrow \frac{1}{x} \text { for } h \rightarrow 0 .
$$

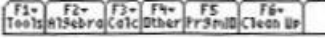

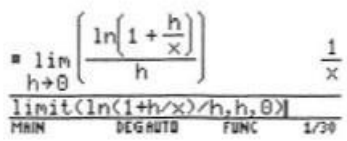

Grænseværdien for differenskvotienten er differentialkvotienten i punktet $x$, så vi făr:

\section{SETNING 8}

Den afledede af den naturlige logaritmefunktion $f(x)=\ln x$ er

$$
f^{\prime}(x)=\frac{1}{x}, x>0 .
$$

Figure 2. A CAS assisted proof for the derivative of the natural logarithm function (Carstensen, Frandsen \& Studsgaard, 2009, p. 164). CAS is activated in step 3 (3. trin) to find the limit. 


\section{Jankvist \& Misfeldt-CAS Assisted Proofs}

This example also concerns a differential quotient, only this time that of the natural logarithm function. The example stems from a 2 nd year textbook. The proof follows a "template" of what in Danish upper secondary mathematics is referred to as the "three-step rule" of differentiation. Now, this is not really a "rule", if anything more a "rule of thumb" to remember the steps for examining whether a given function is differentiable. In step 1 (cf. figure 2), the functional growth, $\Delta y$, is expressed, i.e. rewrite $f(x)$ as $f(x+h)-f(x)$. In step 2 , the difference quotient is expressed by division with $h$. Step 3 is then the evaluation of this expression, i.e. evaluating if $\Delta y / h$ has a limit for $h \rightarrow 0$, and if so, what this limit is. As seen in figure 2, the textbook authors choose to evaluate this limit by means of the "lim" function in CAS, which immediately reveals that the differential quotient is $1 / x$.

The two first steps in the example follow a more or less traditional approach, while the third outsources all reasoning to CAS - and hence, also blackboxes step 3 completely. In the proof as a whole there is an element of systematization, since we apply a general procedure (the three-step rule) to find the differential quotient of a function. Also, the general structure of the proof follows a deductive approach, but with the blackboxing of step 3, the use of CAS may come to support an external conviction proof scheme. In this part of the proof the potential explanatory power in relation to supporting an understanding of why the limit is $1 / x$ is completely suppressed. Of course, this can be used as an enacting of the lever potential. A traditional paper-andpencil proof typically involves algebraic manipulations including the logarithm rules, substitution of variables, as well as calculations with limits. Therefore, the outsourcing to CAS does save time and energy for teacher and students. But this benefit comes at two expenses: (1) the students never get around to consider the details of the limit concept (does the limit even exist, and if so how should it be handled and calculated?); and (2) the proof can be experienced as an unjustified proof ritual3, because the crucial step of the proof is blackboxed, while the structure of the proof is maintained. Clearly, this is not unproblematic. The very reason for organizing the proof around the three-step rule is to convert the problem into a limit process that can be handled algebraically. This may activate two different proof schemes simultaneously; a deductive proof scheme, and an external conviction proof scheme. The argument is organized in the same way as in a classical algebraic proof for the derivative (activating a deductive proof scheme), but we are told by CAS what the limit is (activating an authoritarian proof scheme). The 
three-step rule ends up not being mathematically justified, which compromises the entire proof. It must be expected that this does not make things any easier for students who already are experiencing trouble distinguishing between different forms of mathematical argumentation, as pointed out by Dreyfus (1999), and may even add to what Duval (2007) termed as status confusion.

The CAS use in the proof can be seen as a combination of pragmatic and justificational mediations. CAS conducts a laborious job for the teacher and students and in that sense, it conducts a pragmatic mediation. Furthermore, these calculations ensure the result - a justificational mediation. It is more unclear whether CAS mediates epistemically in this example. The knowledge and insights that the proof mediates is of course the structure of the proof itself (as described above), the fact that the result is established (the derivative of $\ln (x)=1 / x)$, and - and this is where CAS mediates - that the limit of $(\ln (x-(h / x)) / h$ is $1 / x$ for $h \rightarrow 0$. The degree to which this is a meaningful epistemic mediation has to do with the extent to which this "lemma" conveys a meaningful insight to students. We suggest that this is hardly so; for most students the limit is relevant only in the capacity it serves in proving the result regarding the derivative of the natural logarithm. If the epistemic mediation is weak, as is the case in this example of type 2, and the actual value of CAS is found in the pragmatic and justificational mediations, then it might be a reasonable question to ask, why the formula is not "proved" through a complete outsourcing to CAS (type 1), which also justifies the result but in a more efficient way.

\section{Type 3: Additional verification by CAS}

The instances of type 3 mainly concern verification of already calculated limits, derivatives, antiderivatives, and solutions to differential equations. In the following, we provide an example of the latter.

In this example, CAS does not enter into the picture until a traditional proof is completed. The theorem (in the textbook referred to as Theorem 2, see figure 3) concerns differential equations of the type $y^{\prime}+a y=b$ and the complete solution to these differential equations, where $a$ and $b$ are real numbers and $a \neq 0$. The proof builds on a previously proven theorem (in the textbook referred to as Theorem 1), namely that the solution to differential equations of the type $y^{\prime}=k y$, where $k$ is any given constant, is of the form $y=$ 
$c e k x$, where $c$ is an arbitrary constant. The proof as such (cf. figure 3 ) is a fairly straightforward one: firstly rewriting the differential equation $f^{\prime}(x)+a f(x)=b$; then introducing the function $g(x)=f(x)-b / a$; and eventually arriving at an expression the solution of which may be found by relying on Theorem 1. The interesting thing, however, is not the traditional proof itself. It is the use of CAS once the proof is complete. What the authors do is to desolve the general differential equation in CAS, i.e. deSolve $\left(y^{\prime}+a y=b, x\right.$, $y$ ) - as was also done for Theorem 1, cf. the first line in the CAS screenshot, deSolve $\left(y^{\prime}=k y, x, y\right)$ in figure 3 . In fact, they do it frequently throughout the textbook, another example is after a traditional proof for the derivative of the tangent function.

One wonders what the authors intend to achieve by this. Of course, the authors' intentions with the CAS checking practice might be to make students' aware that there are different routes to the verification of results, and that taking several of these routes is a way to check your results. But from a didactical point of view, one worries what impression this actually leaves the students with when using CAS to check theorems that have just been proved.

One might argue that type 3 is merely a traditional proof augmented with a type 1 CAS assisted proof. However, unlike type 1 where CAS served as a justificational mediation, CAS in this case plays more the role of a pragmatic mediation. There is a difference between checking the theorem itself and checking a proof for the theorem for human errors. While justificational mediations would concern the former, pragmatic mediations to a higher degree address the latter. In the above example CAS is simply used for checking for human errors, not to search for mathematical truth or insights. From a proof scheme perspective, on the one hand, students may come to view CAS as the authority against which the deduced mathematical result is checked. Some students may get the impression that the proof is correct, because CAS says so - and not that CAS relays the same result, because the theorem can be proved (as just done). The role of CAS here appears to be to "guarantee" that the result is correct, but without providing any explanation. On the other hand, the use of CAS may also be seen as supporting students' empirical proof scheme, since CAS is used to support verification for this particular incident (theorem). Whether it is one or the other proof scheme that is in play depends on the perception of the student. 
DIFFERENTIALLIGNINGER AF TYPEN $y^{\prime}+a y=b$

Vi skal se på en type differentialligning, der ligner ovenstående meget, og vi benytter sætning 1 .

\section{SAETNING 2}

Den fuldstændige løsning til differentialligningen

$$
\frac{d y}{d x}+a y=b \text { eller } f^{\prime}(x)+a \cdot f(x)=b,
$$

hvor $a$ og $b$ er reelle tal, og $a \neq 0$, er givet ved

$$
y=f(x)=\frac{b}{a}+c \cdot e^{-a x} .
$$

Bevis. Ligningen kan også skrives

$$
f^{\prime}(x)=-a \cdot\left(f(x)-\frac{b}{a}\right),
$$

og vi indfører funktionen $g(x)$ ved parentesens indhold, altså

$$
g(x)=f(x)-\frac{b}{a} \quad \text { eller } f(x)=g(x)+\frac{b}{a} .
$$

Sả er

$$
f^{\prime}(x)=g^{\prime}(x),
$$

og den ligning, vi skal løse, bliver efter (3) til

$$
g^{\prime}(x)=-a \cdot g(x) \text {. }
$$

Efter satning 1 er den fuldstandige løsning til denne ligning givet ved

$$
g(x)=c \cdot e^{-a x},
$$

hvoraf

$$
f(x)=g(x)+\frac{b}{a}=\frac{b}{a}+c \cdot e^{-a x} .
$$

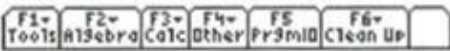

$$
\begin{aligned}
& \text { ' deSolve( } \left.y^{\prime}=k \cdot y, x, y\right) \\
& y=e_{1} \cdot e^{k \cdot x} \\
& \text { - deSolve }\left(y^{\prime}+a \cdot y=b, x, y\right) \\
& y=e 6 \cdot e^{-a \cdot x}+\frac{b}{a} \\
& \frac{\text { deSolve }\left(y^{\prime}+a * y=b, x, y\right)}{\text { Malk }}
\end{aligned}
$$

Figure 3. First the proof, then CAS (Carstensen, Frandsen \& Studsgaard, 2007, p. 84). 


\section{Discussion of potential effects of CAS assisted proofs}

If textbooks do a poor job in enabling students to distinguish between different forms of argumentation, the job is left entirely to the teachers. Often teachers address this by asking students to "explain" and "justify" their reasoning (Dreyfus, 1999). But as pointed to in the EMS solid findings quotation earlier, this is a task which is related also to the students' perception (or beliefs) of mathematics and what it means to do mathematics. Dreyfus says:

...the requirement to explain and justify their reasoning requires students to make the difficult transition from a computational view of mathematics to a view that conceives of mathematics as a field of intricately related structures. This implies acquiring new attitudes and conceiving of new tasks: The central question changes from 'What is the result?' to 'Is it true that...?'. Students thus need to develop new and more sophisticated forms of knowledge. (Dreyfus, 1999, p. 106)

The question from our point of view, of course, is how the introduction of CAS into the act of proving may be expected to affect students' perception of explanation and justification in mathematics as well as their understanding of mathematical argumentation.

In the three different examples of CAS assisted proofs above we have witnessed how CAS is used to justify mathematical insights as part of proofs. Yet, in all three instances, CAS does essentially not provide any explanation (Hanna, 1990) as to why the given theorem, or aspects of it, is true. Although to different degrees, in all of our examples the use of CAS appears to support an external conviction proof scheme, more precisely the authoritarian proof scheme (Harel \& Sowder, 2007). In the first example (figure 1) the entire process of proving and verification is blackboxed through an outsourcing to CAS. In the second example (figure 2) a crucial intermediate step, which could potentially involve an explanatory role, is also blackboxed through an outsourcing to CAS. Elbaz-Vincent (2005) points out the dangers of using CAS to find limits, and further states that "we cannot reasonably use a CAS as a black box, in particular in the classroom" because both teachers and students need "sufficient knowledge of the behaviour of the CAS in order to understand the result for themselves" (p. 63). Perhaps the intention of the textbook authors in our second example has been to use CAS as a lever 
potential, but by attempting so they compromise the explanatory role of mathematical proof while transforming CAS from an instrument to something resembling a mathematical authority, thus making it unnecessary to complete difficult parts of a proof. In the third example (figure 3) CAS does not enter into the actual proof, but only when this is complete as a means for "checking" the correctness of the already proven mathematical result. The intention of the textbook authors could be to endorse a practice where students always check their results by use of their CAS tool. An upper secondary student already experiencing difficulties with the subject of mathematics, may wonder if the theorem is true because CAS says so, or if CAS confirms the theorem because we can prove it. Of course, as a mathematical philosophical question, this is not so easy to answer due to automated theorem provers and experimental mathematics. But regarding the cases of very classical mathematics, as we have seen in the CAS assisted proofs from upper secondary school textbooks, it might not be a productive uncertainty to foster in the mind of the students. Indeed, if some students come to believe that CAS is an important mathematical authority, then this will affect their conception of mathematical argumentation and the discipline as such.

So, clearly it matters how CAS is used in relation mathematical proofs in the teaching and learning of mathematics: it may interfere with students' perception of the notion of mathematical proof and it may promote certain proof schemes over others in the process. Building on the theoretical constructs presented by Artigue (2002) and by Rabardel and Bourmaud (2003), we have proposed to distinguish epistemic, pragmatic and justificational mediations when CAS is used in proving (Misfeldt \& Jankvist, 2018). But how does this relate to the mathematics education theoretical constructs on students' difficulties with proofs and proving? Epistemic mediations are connected to proofs that explain (Hanna, 1990), as well as to deductive proof schemes (Harel \& Sowder, 2007). Justificational mediations are related to proofs that only proves, i.e. without explaining. Furthermore, such mediations are connected to external conviction proof schemes. If statements are true because the CAS says so, CAS mediates a justificational process. Pragmatic mediations may be connected to one or more of the different proof schemes, including the empirical proof scheme, by providing necessary but laborious calculations and manipulations required for a certain argument. Let us revisit the three types of identified CAS assisted proofs, 
keeping in mind that we found 8 instances of type 1,13 instances of type 2 and 17 instances of type 3, when going through 33 upper secondary school mathematics textbooks (cf. table 1).

The first type of CAS assisted proofs involving complete outsourcing to CAS concerns establishing and securing mathematical truth rather than understanding mathematical relations; it may be considered as a justificational mediation providing only "proof", not explanation. These "proofs" are deprived from any real reasoning structure - no real help or guidance is provided by the textbooks. And since information about the truth of a theorem deprived from structure or explanation is similar to asking an external resource/authority, there is a danger that students develop an external conviction proof scheme - more precisely an authoritarian proof scheme - when working with such CAS assisted proofs in textbooks.

The second type of CAS assisted proofs involving partial outsourcing to CAS are as such classical deductive proofs, only some of the arguments are dealt with by a CAS tool as support for the teachers' and students' reasoning process. However, the tool is used to allow students to carry out mathematical operations, involving reasoning, without necessarily possessing the associated mathematical understanding of the objects involved. This was exemplified by the CAS assisted proof where CAS was used to find a limit in order to work with derivatives - not to understand anything about the limit concept. With this in mind, the use of CAS here can be characterized as pragmatic. Other examples of pragmatic mediations are when CAS is used for polynomial division, etc. as part of a proof. But the use of CAS for partial outsourcing may also serve justificational mediations. Previously we mentioned two examples of such CAS assisted proofs in textbooks: one where CAS was used to evaluate if two algebraic expressions equalled each other, and one where CAS was used to test if a given function fulfilled a differential equation. As for epistemic mediations, one might imagine a use of CAS to draw a graph of, say, $y=\ln (1+k) / k$ and even write up a table of its functional values to verify numerically that it approaches 1 for $k \rightarrow 0$. But since such a use of CAS still cannot meet the criteria of a deductive proof per $s e$, it may bear with it the potential danger of promoting an empirical proof scheme with the students. In a similar manner, the justificational mediations mentioned above may promote the authoritarian external conviction proof scheme. Still, the combination in our displayed example of type 2 (figure 2) is the potentially worst which we have come across in the identified CAS 
assisted proofs of this type. The outer structure of the three-step rule may in itself enforce a ritual external conviction proof scheme with the students, while the misguided use of CAS as a lever potential in step 3 promotes an authoritarian proof scheme. The reason that we regard the use of CAS as a misguided lever potential in this case is that it not only blackboxes algebraic manipulations, the of logarithm rules, etc., but that it also blackboxes the existence of the limit and what this actually is. This is to say that CAS blackboxes the involved mathematical reasoning.

The third type of CAS assisted proofs are where classical algebraic proofs are often augmented by a check that the proof is correct by plotting the theorem into CAS. This is a straightforward pragmatic use of CAS as part of a proof that has no explanatory intentions, since the aim simply is to check the algebraic result. Strictly speaking the proof scheme is authoritarian. However, in connection with deductive algebraic proofs the purpose seems to be to check the algebraic solution. The idea that more pieces of evidence are better than just the one proof can be said to build on an empirical proof scheme foreign to mathematics, but the idea of checking results for human errors is of course not.

As pointed to by Dreyfus (1999), most upper secondary school students neither know what a mathematical proof is nor what it is supposed to achieve. Certainly, the use of CAS in the three types of identified CAS assisted proofs do not seem to promote such understanding. And even if the upper secondary students do have some vague idea of the notion of mathematical proof in terms of verification (cf. De Villiers, 1990), the displayed use of CAS does not appear to clarify the involved processes of the act of proving. With reference to Duval's (2007) two identified failures by students in relation to mathematical proving, the use of CAS, as seen above, appears to blur the picture as to "status confusion" by potentially expanding already existing "gaps of deficiencies in the progress of a proof" (p. 159). In this sense, CAS adds yet a component to Dreyfus' (1999, p. 97) list of disturbing elements for students' conception of proof, i.e. that "more or less formal arguments are used, together with visual or intuitive justifications, generic examples, and naive induction" and hence CAS furthers the difficulties for students to distinguish between these different forms of argumentation and reasoning and whether they are all (equally) acceptable. 


\section{Conclusion and final reflections}

In this article, we have described how CAS is used in Danish upper secondary textbooks. We have done so based on a quantitative analysis of 33 textbooks and a qualitative analysis of these textbooks' use of CAS in relation to proofs and proving. The result that the didactical use of CAS has some problems when it comes to its use in proving in textbooks, does not mean that CAS is not a useable tool for learning and working with mathematics. But so far research has to a large extent focused on students' CAS use when working on mathematical assignments (Laborde \& Strässer 2010; Lagrange 2005; Trouche 2005), or the way teaching with CAS is organized, or how it affects teachers' work (see Laborde and Strässer, 2010 for specific references). Hence, the use of CAS in institutionalized arguments such as textbook proofs has not been thoroughly investigated. This bias is also evident in the main constructs of epistemic and pragmatic values that we have relied on throughout this article.

Our analyses show that the most interesting use of CAS in textbook proofs is within the partial outsourcing category (type 2). Such proofs potentially adopt the lever potential when outsourcing certain processes to CAS. From the analysis of the type 2 example (figure 2) we see that the details of such an outsourcing process are important, since there is a risk that mathematically critical aspects of a proof is outsourced. However, another problem is that the use of lever potential in relation to textbook elements, such as proofs, might end up crippling the students mathematically for two reasons. Firstly, such use of CAS deprives students the experience of reading mathematical texts possible to follow using only their minds. Secondly, it is often the case that much more than intentioned is blackboxed when adopting the lever potential. In the type 2 example the mathematical reasoning is blackboxed to a larger degree than intentioned. Other examples might be blackboxing of algebraic skills, which students might benefit from training. Hence, there is a risk that the "lever" in the lever potential ends up acting as a "walking frame" for the students instead.

The results of the analyses in this article can be seen as providing guidelines both for practice and for future research. First of all, we see that the use of CAS as part of textbook proofs can be a problematic practice, and if indeed pursued several issues need to be taken into account. When developing textbook proofs that build on CAS, authors need to think about 
how and to what extent the adoption of the lever potential can lead to CAS use that blackboxes critical concepts or reasoning processes. Furthermore, in this article we have used justificational mediations. We show the value of this construct in our analyses, since it allows us to distinguish important differences in how CAS is referred to in proofs in textbooks. However, we do only know little about how students experience their use of CAS, in proving as well as in problem solving, in the light of this term. Do students think about justification, insight and performing mathematical labor as different things and how? Is the distinction between epistemic, pragmatic and justificational mediations usable to understand CAS use in other elements of textbooks than proofs, e.g. use of CAS in examples? Such questions could be explored empirically, and that would allow us to see to what extent the concept of justificational mediation contribute to mathematics education. It is our intention to do so in the future, beginning with the 586 instances of CAS use in examples in the Danish textbooks (cf. table 1).

In summary, the investigation of this article suggests a potential problem with using CAS as an integrated part of deductive mathematical proofs in textbooks, the reason being that it appears to promote authoritarian proof schemes. Relying on CAS in a justificational manner and being interested only in results and not in relations and conceptual issues, goes counter to the idea of a deductive proof and may push the students' argumentation in an authoritative direction. Only this authority is not made up by teachers, mathematicians, or mathematics textbooks, but by a Computer Algebra System and hence promotes a kind of techno-authoritarian external conviction proof scheme (Misfeldt \& Jankvist, 2018) with the students. If students possess such a proof scheme, they may even believe that CAS assisted proofs are quite sufficient to establish truth in mathematics. So, not only will they not be able to mathematically prove anything, but it may also be very difficult to convince them of the fact that they have not. Such a techno-authoritarian proof scheme poses, we believe, a major and multifaceted issue in the education of future mathematics students.

\section{Acknowledgements}

We thank Anders Marcussen and Kasper Bjering Søby Jensen for initially drawing our attention to the textbooks' CAS assisted proofs as well as for fruitful discussions of possible interpretations. 


\section{Foodnotes}

1The term "CAS proof" (CP) is used by Flynn \& MacCrae (2001), with reference to a categorization by MacAogáin (2000), in a context of CAS and assessment, but CAS Proof here means something very different, since it refers to test items which are CAS Proof (kind of like bulletproof), i.e. where the advantage of availability of CAS is minimal or non-existing. 2 E.g. see: http://i-bog2.dk/bog/gyldendals-gymnasiematematik-a-4200.html\#/14 3 For an elaborate discussion of proof rituals, see Vinner (2007).

\section{References}

Appel, K. \& Haken, W. (1977). Solution of the four color map problem.

Scientific American, 237(4), 108-121. Retrieved from:

https://www.jstor.org/stable/24953967

Artigue, M. (2002) Learning mathematics in a CAS environment: the genesis of a reflection about instrumentation and the dialectics between technical and conceptual work. International Journal of Computers for Mathematical Learning, 7(3), 245-274. doi: 10.1023/A:1022103903080

Artigue, M. (2010). The future of teaching and learning mathematics with digital technologies. In: C. Hoyles and J.-B. Lagrange (Eds.), Mathematics Education and Technology-Rethinking the Terrain (pp. 463-475). New York, USA: Springer.

Borwein, J. (2005). The experimental mathematician: the pleasure of discovery and the role of the proof. International Journal of Computers for Mathematical Learning, 10, 75-108. doi: 10.1007/s10758-005-5216-X

Buchberger, B. (2002). Computer algebra: the end of mathematics? ACM SIGSAM Bulletin, 36(1), 3-9.

Carstensen, J., Frandsen, J. \& Studsgaard, J. (2007). Mat A3, stx. Aarhus: Systime.

Carstensen, J., Frandsen, J. \& Studsgaard, J. (2009). Mat C til B, stx. Aarhus: Systime.

Clausen, F., Schomacker, G. \& Tolnø, J. (2007). Gyldendals

Gymnasiematematik. Grundbog A. København: Gyldendalske Boghandel, Nordisk Forlag A/S.

Dana-Picard, T. (2005). Some reflections on CAS assisted proofs of theorems. International Journal for Technology in Mathematics 
Education, 12(4), 165-171. Retrieved from:

https://search.proquest.com/docview/203441136?accountid=8194

De Villiers, M. (1990). The role and function of proof in mathematics.

Pythagoras, 24, 17-24.

Dreyfus, T. (1994). The role of cognitive tools in mathematics education.

In: R. Biehler, R. W. Scholz, R., Strässer and B. Winkelmann (Eds.),

Didactics of Mathematics as a Scientific Discipline (pp. 201-211).

Dordrecht, The Netherlands: Kluwer.

Dreyfus, T. (1999). Why Johnny can't prove. Educational Studies in

Mathematics, 38(1-3), 85-109. doi: 10.1007/978-94-017-1584-3_5

Duval, R. (2007). Cognitive functioning and the understanding of

mathematical processes of proof. In: P. Boero (Ed.) Theorems in

school: From history, epistemology and cognition to classroom

practice (pp. 137-161). Rotterdam: Sense Publishers.

Education Committee of the EMS (2011). Do theorems admit exceptions?

Solid findings in mathematics education on empirical proof schemes.

Newsletter of the European Mathematical Society, 82, 50-53.

Elbaz-Vincent P. (2005) A CAS as an assistant to reasoned instrumentation.

In: Guin, D., Ruthven, K. and Trouche L. (Eds.) The Didactical

Challenge of Symbolic Calculators. Mathematics Education Library, vol 36. Boston, MA: Springer.

Flynn, P. \& MacCrae, B. (2001). Issues in assessing the impact of CAS on mathematics examinations. Proceedings of 24th Conference of the Mathematics Education Research Group of Australasia (pp. 222230). Retrieved from:

https://www.merga.net.au/documents/RR_Flynn\&McCrae.pdf

Hanna, G. (1989). Proofs that prove and proofs that explain. In: G.

Vergnaud, J. Rogalski and M. Artigue (Eds.), Proceedings of the 13th Conference of the International Group for the Psychology of Mathematics Education, Vol. 2 (pp. 45-51). Paris: CNRS.

Hanna, G. (1990). Some pedagogical aspects of proof. Interchange, 21(1), 6-13.

Harel, G. \& Sowder, L. (2007). Toward comprehensive perspectives on the learning and teaching of proof. In: F. K. Lester Jr. (Ed.), Second Handbook of Research on Mathematics Teaching and Learning (pp. 805-842). Charlotte, NC: Information Age Publishing. 
Hoyles, C. (2014). Solid findings in mathematics education: the influence of the use of digital technology on the teaching and learning of mathematics in schools. Newsletter of the European Mathematical Society, 91, 49-51.

Hoyles, C., \& Lagrange, J. B. (2010). Mathematics education and technology: Rethinking the terrain. Berlin: Springer.

Jankvist, U. T. \& Misfeldt, M. (2015). CAS-induced difficulties in learning mathematics? For the Learning of Mathematics, 35(1), 15-20.

Jankvist, U. T., Misfeldt, M. \& Aguilar, M. S. (2019). What happens when CAS-procedures are objectified? - the case of "solve" and "desolve". Educational Studies in Mathematics, 101(1), 67-81. doi:

10.1007/s10649-019-09888-5

Jankvist, U. T., Misfeldt, M. \& Aguilar, M. S. (in press). Tschirnhaus' transformation: mathematical proof, history and CAS. In E. Barbin, U. T. Jankvist, T. H. Kjeldsen, B. Smestad \& C. Tzanakis (Eds.), Proceedings of the Eighth European Summer University on History and Epistemology in Mathematics Education ESU 8. Oslo Metropolitan University.

Jankvist, U. T., Misfeldt, M. \& Marcussen, A. (2016). The didactical contract surrounding CAS when changing teachers in the classroom. REDIMAT Journal of Research in Mathematics Education, 5(3), 263-286. doi: 10.17583/redimat.2016.2013

Johansen, M. W. \& Misfeldt, M. (2016). Computers as a Source of a Posteriori Knowledge in Mathematics. International Studies in the Philosophy of Science, 30(2), 111-127. doi:

10.1080/02698595.2016.1265862

Laborde, C. \& Strässer, R. (2010). Place and use of new technology in the teaching of mathematics: ICMI activities in the past 25 years. ZDM International Journal on Mathematics Education, 42(1), 121133.doi: 10.1007/s11858-009-0219-z

Lagrange, J. (2005). Using symbolic calculators to study mathematics: the case of tasks and techniques. In: D. Guin, K. Ruthven and L. Trouche (Eds.), The didactical challenge of symbolic calculators: Turning a computational device into a mathematical instrument (pp. 113-135). New York, NY: Springer. 
Lavicza, Z. (2010). Integrating technology into mathematics teaching at the university level. ZDM - International Journal on Mathematics Education, 42(1),105-119. doi: 10.1007/s11858-009-0225-1

MacAogáin, E. (2000). Assessment in the CAS age: An Irish perspective. Paper presented at the 6th ACDCA Summer Academy.

McEvoy, M. (2008). The epistemological status of computer-assisted proofs; Philosophia Mathematica, 16(3), 374-387.

Misfeldt, M. \& Jankvist, U. T. (2018). Instrumental genesis and proof: understanding the use of computer algebra systems in proofs in textbook. In. L. Ball, P. Drijvers, S. Ladel, H.-S. Siller, M. Tabach and C. Vale (Eds.), Uses of technology in K-12 mathematics education: Tools, topics and trends (pp. 375-385). Heidelberg: Springer Verlag.

Misfeldt, M. \& Zacho, L. (2016). Supporting primary-level mathematics teachers' collaboration in designing and using technology-based scenarios. Journal of Mathematics Teacher Education, 19(2-3), 227241.doi: 10.1007/s10857-015-9336-5

Nabb, K. A. (2010) CAS as a restructuring tool in mathematics education. In: P. Bogacki (Ed.) Electronic Proceedings of the 22nd International Conference on Technology in Collegiate Mathematics (pp. 247-259). Retrieved from: http://archives.math.utk.edu/ICTCM/v22.html

Niss, M. (1999). Aspects of the nature and state of research in mathematics education. Educational Studies in Mathematics, 40(1), 1-24. doi: 10.1023/A:1003715913784

Ottesen, S. T. (2009). Relating university mathematics teaching practices and students' solution processes. PhD Thesis. Tekster fra IMFUFA, no. 463. Roskilde: Roskilde University. Retrieved from: http://milne.ruc.dk/imfufatekster/pdf/463.pdf

Rabardel, P. \& Bourmaud, G. (2003). From computer to instrument system: a developmental perspective. Interacting with Computers, 15(5), 665-691.

Steiner, M. (1978). Mathematical explanation. Philosophical Studies, 34, 135-151. Retrieved from: https://www.jstor.org/stable/4319237

Trouche, L. (2005). Instrumental genesis, individual and social aspects. In: D. Guin, K. Ruthven and L. Trouche (Eds.), The Didactical Challenge of Symbolic Calculators: Turning a Computational Device 
into a Mathematical Instrument (pp. 197-230). New York, NY:

Springer.

Tymoczko, T. (1979). Four-color problem and its philosophical

significance. Journal of Philosophy, 76(2), 57-83.doi:

$10.2307 / 2025976$

UVM (2013). Bekendtgфrelse om uddannelsen til studentereksamen.

Matematik A, stx, bilag 35. København: Undervisningsministeriet (UVM). Retrieved from:

https://www.retsinformation.dk/Forms/R0710.aspx?id=152507\#Bil3 5

Verillon, P. \& Rabardel, P. (1995). Cognition and artifacts: A contribution to the study of thought in relation to instrumented activity. European Journal of Psychology of Education, 10(1), 77-101. Retrieved from: https://www.jstor.org/stable/23420087

Vinner, S. (2007). Mathematics education: procedures, rituals and man's search for meaning. Journal of Mathematical Behavior, 26, 1-10.doi: 10.1016/j.jmathb.2007.03.004

Winsløw, C. (2003). Semiotic and discursive variables in CAS-based didactical engineering. Educational Studies in Mathematics, 52(3), 271-188.doi: 10.1023/A:1024201714126

Uffe Thomas Jankvist is professor of mathematics education at Aarhus University, Denmark.

Morten Misfeldt is professor of mathematics education at University of Copenhagen, Denmark.

Contact Address: Direct correspondence concerning this article, should be addressed to the author. Postal Address: Danish School of Education, Aarhus University, Campus Emdrup, Tuborgvej 164, DK2400 Copenhagen NV. E-mail: utj@edu.au.dk 


\section{Appendix A}

\begin{tabular}{|c|c|c|c|c|c|c|}
\hline Reference & $\begin{array}{l}\text { CAS in } \\
\text { proofs }\end{array}$ & $\begin{array}{l}\text { CAS in } \\
\text { conceptual } \\
\text { work }\end{array}$ & $\begin{array}{l}\text { CAS in } \\
\text { introductory } \\
\text { text }\end{array}$ & $\begin{array}{l}\text { CAS in } \\
\text { Macros }\end{array}$ & $\begin{array}{l}\text { CAS in } \\
\text { examples }\end{array}$ & $\begin{array}{c}\text { other use of } \\
\text { CAS }\end{array}$ \\
\hline $\begin{array}{l}\text { 1. Carstensen, J., Frandsen, J., } \\
\text { \& Studsgaard, J. (2010).Mat C } \\
\text { stx(2. udgave ed.). Århus: } \\
\text { Systime. }\end{array}$ & 0 & 0 & 0 & 2 & 0 & 0 \\
\hline $\begin{array}{l}\text { 2. Carstensen, J., Frandsen, J., } \\
\text { \& Studsgaard, J. (2009).Mat C } \\
\text { hhx(3. udgave ed.). Arrhus: } \\
\text { Systime. }\end{array}$ & 0 & 10 & 0 & 18 & 17 & 0 \\
\hline $\begin{array}{l}\text { 3. Fristrup, D., Nørgaard, S. \& } \\
\text { Rasmussen, E. S. (2010). Mat } \\
\text { C hf(2. udgave ed.). Århus: } \\
\text { Systime }\end{array}$ & 0 & 9 & 0 & 1 & 0 & 0 \\
\hline $\begin{array}{l}\text { 4. Carstensen, J., Frandsen, J., } \\
\text { \& Studsgaard, J. (2006).Mat C } \\
\text { til B stx. Århus: Systime. }\end{array}$ & 9 & 0 & 0 & 2 & 18 & 0 \\
\hline $\begin{array}{l}\text { 5. Carstensen, J., Frandsen, J., } \\
\text { Studsgaard, J. (2015).Mat B } \\
\text { hf(2. udgave ed.). Århus: } \\
\text { Systime. }\end{array}$ & 0 & 0 & 0 & 0 & 0 & 0 \\
\hline
\end{tabular}




\begin{tabular}{|c|c|c|c|c|c|c|}
\hline Reference & $\begin{array}{l}\text { CAS in } \\
\text { proofs }\end{array}$ & $\begin{array}{c}\text { CAS in } \\
\text { conceptual } \\
\text { work }\end{array}$ & $\begin{array}{c}\text { CAS in } \\
\text { introductory } \\
\text { text }\end{array}$ & $\begin{array}{l}\text { CAS in } \\
\text { Macros }\end{array}$ & $\begin{array}{l}\text { CAS in } \\
\text { examples }\end{array}$ & $\begin{array}{c}\text { other use of } \\
\text { CAS }\end{array}$ \\
\hline $\begin{array}{l}\text { 6. Jensen M. \& Marthinus K. } \\
\text { (2008).MAT B1 htx(2. udgave } \\
\text { ed.). Arhus : Systime. }\end{array}$ & 0 & 0 & 1 & 4 & 13 & 0 \\
\hline $\begin{array}{l}\text { 7. Carstensen, J., Frandsen, J., } \\
\text { Studsgaard, J. (2013).Mat B1 } \\
\text { stx.(3. udgave ed.). Århus: } \\
\text { Systime. }\end{array}$ & 0 & 0 & 0 & 0 & 0 & 0 \\
\hline $\begin{array}{l}\text { 8. Carstensen, J., Frandsen, J., } \\
\text { Studsgaard, J. (2013).Mat B2 } \\
\text { stx.(3. udgave ed.). Århus: } \\
\text { Systime. }\end{array}$ & 0 & 0 & 0 & 0 & 1 & 0 \\
\hline $\begin{array}{l}\text { 9. Jensen M. \& Marthinus K. } \\
\text { (2007).MAT B2 htx(1. udgave } \\
\text { ed.). Arhus : Systime. }\end{array}$ & 0 & 0 & 0 & 1 & 22 & 0 \\
\hline $\begin{array}{l}\text { 10. Carstensen, J., Frandsen, J., } \\
\text { Studsgaard, J. (2007).Mat B til } \\
\text { A stx.(1. udgave ed.). Århus: } \\
\text { Systime. }\end{array}$ & 3 & 2 & 0 & 0 & 29 & 1 \\
\hline
\end{tabular}




\begin{tabular}{lcccccc}
\hline Reference & $\begin{array}{c}\text { CAS in } \\
\text { proofs }\end{array}$ & $\begin{array}{c}\text { CAS in } \\
\text { conceptual } \\
\text { work }\end{array}$ & $\begin{array}{c}\text { CAS in } \\
\text { introductory } \\
\text { text }\end{array}$ & $\begin{array}{c}\text { CAS in } \\
\text { Macros }\end{array}$ & $\begin{array}{c}\text { CAS in } \\
\text { examples }\end{array}$ & $\begin{array}{c}\text { other use of } \\
\text { CAS }\end{array}$
\end{tabular}

11. Jensen, T \& Nielsen M. O. (2013).Matema10k -

Matematik for stx C-Niveau.

(2. udgave). Frederiksberg C:

Frydenlund.

12. Jensen, T, Jessen, C. \&

Nielsen M. O.

(2006).Matema10k -

Matematik for gymnasiet B-

Niveau. (1. udgave).

Frederiksberg C: Frydenlund.

13. Jensen, T, Jessen, C. \&

Nielsen M. O.

0

0

0

0

0

1

1

(2006).Matema10k -

Matematik for hf B-Niveau. (1.

udgave). Frederiksberg C:

Frydenlund. 


\begin{tabular}{|c|c|c|c|c|c|c|}
\hline Reference & $\begin{array}{l}\text { CAS in } \\
\text { proofs }\end{array}$ & $\begin{array}{l}\text { CAS in } \\
\text { conceptual } \\
\text { work }\end{array}$ & $\begin{array}{c}\text { CAS in } \\
\text { introductory } \\
\text { text }\end{array}$ & $\begin{array}{l}\text { CAS in } \\
\text { Macros }\end{array}$ & $\begin{array}{l}\text { CAS in } \\
\text { examples }\end{array}$ & $\begin{array}{c}\text { other use of } \\
\text { CAS }\end{array}$ \\
\hline $\begin{array}{l}\text { 14. Jensen, T \& Nielsen M. O. } \\
\text { (2005). Matema10k - } \\
\text { Matematik for hf C-Niveau. (1. } \\
\text { udgave). Frederiksberg C: } \\
\text { Frydenlund }\end{array}$ & 0 & 0 & 0 & 0 & 2 & 1 \\
\hline $\begin{array}{l}\text { 15. Axelsen, R \& Dalsgaard, O. } \\
\text { (2016). Matema10k - } \\
\text { Matematik for hhx B- } \\
\text { Niveau.(1. udgave). } \\
\text { Frederiksberg C: Frydenlund }\end{array}$ & 0 & 1 & 4 & 0 & 4 & 0 \\
\hline $\begin{array}{l}\text { 16. Jensen, T., Jessen, C. \& } \\
\text { Nielsen M. O. (2007). } \\
\text { Matema10k - Matematik for } \\
\text { gymnasiet A-Niveau. } \\
\text { Frederiksberg C: Frydenlund }\end{array}$ & 1 & 5 & 0 & 0 & 22 & 0 \\
\hline $\begin{array}{l}\text { 17. Bregendal, P., Schmidt, S. } \\
\text { N. \& Vestergaard, L. (2012). } \\
\text { Mat B hhx(2. Udgave). Århus: } \\
\text { Systime. }\end{array}$ & 1 & 7 & 1 & 0 & 27 & 0 \\
\hline
\end{tabular}




\begin{tabular}{lcccccc}
\hline Reference & $\begin{array}{c}\text { CAS in } \\
\text { proofs }\end{array}$ & $\begin{array}{c}\text { CAS in } \\
\text { conceptual } \\
\text { work }\end{array}$ & $\begin{array}{c}\text { CAS in } \\
\text { introductory } \\
\text { text }\end{array}$ & $\begin{array}{c}\text { CAS in } \\
\text { Macros }\end{array}$ & $\begin{array}{c}\text { CAS in } \\
\text { examples }\end{array}$ & $\begin{array}{c}\text { other use of } \\
\text { CAS }\end{array}$
\end{tabular}

18. Bregendal, P., Schmidt, S.

N. \& Vestergaard, L.

0

0

5

5

0

(2007).Mat A hhx(1. Udgave).

Århus: Systime.

19. Bohnstedt, A., Hansen, B., Jensen, M. \& Marthinus, K.

(2008). Mat A htx (1. Udgave).

Århus: Systime.

20. Carstensen, J., Frandsen, J.,

A1 stx (3. udgave). Århus:

Systime.

21. Carstensen, J., Frandsen, J.,

\& Studsgaard, J. (2006).Mat A2 stx(1. udgave). Århus:

Systime.

22. Carstensen, J., Frandsen, J., \& Studsgaard, J. (2007). Mat A3 stx (1. udgave). Århus: Systime. 


\begin{tabular}{|c|c|c|c|c|c|c|}
\hline Reference & $\begin{array}{l}\text { CAS in } \\
\text { proofs }\end{array}$ & $\begin{array}{c}\text { CAS in } \\
\text { conceptual } \\
\text { work }\end{array}$ & $\begin{array}{c}\text { CAS in } \\
\text { introductory } \\
\text { text }\end{array}$ & $\begin{array}{l}\text { CAS in } \\
\text { Macros }\end{array}$ & $\begin{array}{l}\text { CAS in } \\
\text { examples }\end{array}$ & $\begin{array}{c}\text { other use of } \\
\text { CAS }\end{array}$ \\
\hline
\end{tabular}

23. Hansen, H. H., Melin, J., Poulsen, N. H. \& Weile, J.

(2011) Matematik C (4. udgave) Århus: Systime.

24. Antonius, S. Hansen, H. H., 0

0

5

103

0

Melin, J., Nielsen, K. E. \&

Weile, J. (2011) Matematik B

(3. udgave) Århus: Systime.

25. Bregendal, P., Clausen, R., Hansen, H. H., Poulsen, N. H. og Weile, J. (2003) Matematik A (4. udgave). Århus: Systime.

26. Grøn, B., Felsager, B., 0 0 0

5

.

.

Bruun, B. \& Lyndrup, O.

(2011).Hvad er matematik?

C(1. udgave). København:

L\&R Uddannelse. 


\begin{tabular}{|c|c|c|c|c|c|c|}
\hline Reference & $\begin{array}{l}\text { CAS in } \\
\text { proofs }\end{array}$ & $\begin{array}{c}\text { CAS in } \\
\text { conceptual } \\
\text { work }\end{array}$ & $\begin{array}{c}\text { CAS in } \\
\text { introductory } \\
\text { text }\end{array}$ & $\begin{array}{l}\text { CAS in } \\
\text { Macros }\end{array}$ & $\begin{array}{l}\text { CAS in } \\
\text { examples }\end{array}$ & $\begin{array}{c}\text { other use of } \\
\text { CAS }\end{array}$ \\
\hline
\end{tabular}

27. Grøn, B., Felsager, B.,

0

4

0

0

16

0

Bruun, B. \& Lyndrup, O.

(2012). Hvad er matematik? B

(1. udgave). København: L\&R

Uddannelse.

28. Grøn, B., Felsager, B.,

Bruun, B. \& Lyndrup, O.

0

2

0

9

0

(2013). Hvad er matematik? A

(2. udgave). København: L\&R

Uddannelse.

29. Madsen, P. (2010). Teknisk

Matematik (4. Udgave).

0

0

0

0

81

0

Erhvervsskolernes Forlag.

30. Clausen, F., Schomacker,

2

0

0

0

34

0

G., Tolnø, J. (2017).

Gyldendals

Gymnasiematematik - I-bog A.

Gyldendal 


\begin{tabular}{|c|c|c|c|c|c|c|}
\hline Reference & $\begin{array}{l}\text { CAS in } \\
\text { proofs }\end{array}$ & $\begin{array}{l}\text { CAS in } \\
\text { conceptual } \\
\text { work }\end{array}$ & $\begin{array}{c}\text { CAS in } \\
\text { introductory } \\
\text { text }\end{array}$ & $\begin{array}{l}\text { CAS in } \\
\text { Macros }\end{array}$ & $\begin{array}{l}\text { CAS in } \\
\text { examples }\end{array}$ & $\begin{array}{l}\text { other use of } \\
\text { CAS }\end{array}$ \\
\hline $\begin{array}{l}\text { 31. Clausen, F., Schomacker, } \\
\text { G., Toln } \varnothing, \text { J. (2017). } \\
\text { Gyldendals } \\
\text { Gymnasiematematik - I-bog } \\
\text { B1. Gyldendal }\end{array}$ & 9 & 0 & 0 & 0 & 16 & 0 \\
\hline $\begin{array}{l}\text { 32. Clausen, F., Schomacker, } \\
\text { G., Toln } \varnothing \text {, J. (2017). } \\
\text { Gyldendals } \\
\text { Gymnasiematematik - I-bog } \\
\text { B2. Gyldendal }\end{array}$ & 2 & 0 & 3 & 0 & 28 & 0 \\
\hline $\begin{array}{l}\text { 33. Clausen, F., Schomacker, } \\
\text { G., Toln } \varnothing \text {, J. (2017). } \\
\text { Gyldendals } \\
\text { Gymnasiematematik - I-bog C. } \\
\text { Gyldendal }\end{array}$ & 2 & 0 & 0 & 0 & 9 & 0 \\
\hline SUM & 38 & 44 & 24 & 47 & 586 & 3 \\
\hline
\end{tabular}

